\title{
Hydrophobicity of an Entisol under loblolly pine (Pinus taeda) plantation
}

\author{
Claudia M.B.F. Maia ${ }^{1}$, Cristiane Regina Budziak Fukamachi², Yorleni C. Cambronero ${ }^{3}$, Renato Antônio Dedecek ${ }^{1}$, \\ Antonio Sálvio Mangrich ${ }^{3}$, Kelly Mayuni Narimoto ${ }^{4}$, Débora M. B. P. Milori ${ }^{4}$, Marcelo Luiz Simões ${ }^{4}$ \\ 1Embrapa Forestry, Estrada da Ribeira, Km 111, CP 319, CEP 83411-000, Colombo, PR, Brazil, claudia.maia@cnpf.embrapa.br; \\ dedecek@terra.com.br; ${ }^{2}$ Coordenação de Química, UTFPR, PR, Via do Conhecimento, Km 1, CEP 85503-390, Pato Branco, PR, Brazil, \\ cristianerbf@utfpr.edu.br; 'Departamento de Química, UFPR, Centro Politécnico, CP 19081, CEP 81531-980, Curitiba, PR, Brazil, \\ yorchang@hotmail.com; mangrich@quimica.ufpr.br; ${ }^{4}$ Embrapa Agricultural Instrumentation, Rua XV de Novembro, 1452 CP 741, CEP \\ 13560-970, São Carlos, SP, Brazil, kellymn@iqsc.usp.br; debora@cnpdia.embrapa.br; marcelo@cnpdia.embrapa.br
}

\begin{abstract}
The understanding of soil carbon stabilization processes can be very useful in the development of mitigation techniques for $\mathrm{CO}_{2}$ emissions and global warming. The greater the hydrophobicity of soil organic matter the more stabilized soil organic carbon. Therefore, hydrophobicity can be a sensitive index to characterize the 'quality' of soil organic matter. In this context, the present work aimed to characterize the chemical structures of humic acids collected at three different depths in a hydrophobic Entisol (Neossolo) under loblolly plantation. The results of spectroscopic and chemical analyses (UV-Vis, fluorescence, EPR and X-ray diffractometry) indicated that, as soil depth increased, so did the content of conjugated organic structures, aromatic groups, and free organic radicals, leading to higher humification indices. Aliphatic groups in these fractions were more concentrated in the surface layer than in deeper ones, which can be explained by the constant input of litter. The greater hydrophobicity of the surface soil sample was due to these non-humic components of the organic matter, as suberin and cutin.
\end{abstract}

Index terms: Humic acids, water repellency, forest soil, fluorescence, EPR, X-ray.

\section{Hidrofobicidade em Neossolo litólico sob plantação de Pinus taeda}

Resumo - Compreender os processos de estabilização do carbono no solo pode ser muito útil no desenvolvimento de técnicas de mitigação das emissões de $\mathrm{CO}_{2}$ e do aquecimento global. Quanto maior a hidrofobicidade da matéria orgânica do solo, mais estabilizado é o carbono do solo. Portanto, a hidrofobicidade pode ser usada como indicador para caracterizar a qualidade da matéria orgânica do solo. O presente trabalho caracterizou as estruturas químicas de ácidos húmicos extraídos de solos coletados a três profundidades de um Neossolo sob plantação de Pinus taeda. Os resultados das análises espectroscópicas e químicas (ultra-violeta, fluorescência, ressonância paramagnética eletrônica e difração de raio-X) indicaram que a ocorrência de estruturas conjugadas, grupos aromáticos e radicais orgânicos livres e, portanto, maiores índices de humificação, aumentaram com a profundidade do solo. Grupos alifáticos na fração húmica estavam mais concentrados nas camadas superficiais, o que pode ser explicado pelo constante aporte de liteira na superfície. Testes da repelência à água apontaram maior hidrofobicidade na superfície do solo, provavelmente devido a componentes não húmicos da matéria orgânica, tais como suberina e cutina.

Termos para indexação: Solos florestais, repelência à água, RPE, fluorescência, raio-X.

\section{Introduction}

A mechanistic understanding of soil carbon stabilization can be very useful in developing $\mathrm{CO}_{2}$ emission and global warming mitigation techniques. This biospheric fraction shelters the largest terrestrial carbon pool, which is estimated at 2,300 Gt C in the top $3 \mathrm{~m}$ of soil (Jobbágy \& Jackson, 2000; Lorenz et al., 2007). According to Lützow et al. (2006), important processes that can reduce the accessibility of soil organic matter (SOM) to degradation are: occlusion of organic matter $(\mathrm{OM})$ by aggregation; intercalation of $\mathrm{OM}$ within phyllosilicates and other inorganic lamellar structures; hydrophobicity of OM; and encapsulation in other organic macromolecules. Therefore, the hydrophobic nature of OM plays an important role in soil carbon protection, organic matter dynamics, microbial biomass production, aggregate stability, water infiltration, 
leaching of organic and inorganic pollutants, and in the chemical composition and dynamics of dissolved organic matter (Capriel, 1997). A higher hydrophobicity of SOM appears to stabilize the soil's organic C, caused either by a specific reduced biodegradability of $\mathrm{OM}$ or indirectly by increased aggregate stability (Bachmann et al., 2008). Thus, hydrophobicity can be a sensitive index to characterize the 'quality' of SOM (Capriel, 1997). On the other hand, hydrophobicity or soil water repellency can also lead to the reduced water affinity of soils, causing them to resist wetting for periods ranging from a few seconds to hours, days or weeks (Doerr et al., 2000). Soil water repellency is a common phenomenon in forest soils and is usually attributed to the hydrophobic nature of OM (Doerr et al., 2000; Buczko et al., 2005). In addition to fungal and other microbiological metabolites, many plant species, especially coniferous and resinous trees, produce hydrophobic compounds, resulting in a hydrophobic compounds-rich litter. The compounds identified in water-repellent soils can be divided into two main groups: the long-chain aliphatic hydrocarbons and the amphiphilic hydrocarbons, with both hydrophilic and hydrophobic (structure) ends, which are frequently found in suberin and cutin (Doerr, et al., 2000; Hansel et al., 2008). Recently, Hansel et al. (2008) suggested that large amounts of preserved cutin and suberin in soil could be the principal constituents of the hydrophobic organic layer that prevents the penetration of water in an Entisol repellent soil.

It is well known that SOM is a complex mixture composed mainly of plant residues and excretions, whose chemical composition varies from biopolymers (such as lignin, cellulose, protein, suberin, and cutin) to small molecules (saccharides, organic acids, amino acids, and terpenes), in different phases of decomposition or humification. Considering that OM solubility-based fractionation (humic fractions at different $\mathrm{pHs}$, as in Swift, 1996) does not distinguish between humic and non-humic structures due to operational reasons, any humic acid (HA) fraction shall contain some hydrophobic components originating from plant metabolism without undergoing any chemical transformation. Therefore, studies about hydrophobicity of humic substances are not always associated, to compounds which cause soil water repellency.

Many spectroscopic techniques can be used to chemically characterize SOM. The $465 \mathrm{~nm}\left(\mathrm{E}_{4}\right)$ and $665 \mathrm{~nm}\left(\mathrm{E}_{6}\right)$ absorptions, for example, are used to estimate the $\mathrm{E}_{4} / \mathrm{E}_{6}$ ratio, which is associated with the degree of condensation and conjugation (Chen et al., 1977). The $270 \mathrm{~nm}\left(\mathrm{~A}_{2}\right)$ and $407 \mathrm{~nm}\left(\mathrm{~A}_{4}\right)$ wavelengths have been used to estimate the $\mathrm{A}_{2} / \mathrm{A}_{4}$ ratio, which is employed to distinguish the marine and terrestrial origin of humic and fulvic acids (Fooken \& Liebezeit, 2000). Fluorescence spectroscopy by UV-visible light provides information about the origin, genesis and nature of SOM (Senesi et al., 1991). This technique is also used to identify molecular structures and their functionalities, and the presence of heavy metal and organic contaminants (Senesi, 1990). With its high sensitivity and selectivity, this technique highlights only fluorescent chemical groups. Fluorescence spectra of humic substances result from the sum of the individual spectra of different fluorophore groups that are present in these complex and heterogeneous samples (Milori et al., 2002). Electronic Paramagnetic Resonance provides information about free organic radicals associated with conjugated structures and phenols (Stevenson, 1994), usually from aromatic compounds responsible in part for the hydrophobicity of SOM.

This work aims to characterize the chemical structures of humic acids collected at three different depths in a hydrophobic Entisol under loblolly pine plantation and to correlate the hydrophobic indices determined by different spectroscopic techniques.

\section{Materials and Methods}

Soils samples were collected in a 16 year-old loblolly (Pinus taeda) plantation at Piraí do Sul, Paraná, in southern Brazil. The soil was classified as a litholic dystrophic Neossolo, according to the Brazilian soil classification system (Sistema..., 1999), as a Lithosol, according to the FAO soil classification system, or Entisol, according with US Soil Taxonomy, medium texture, wavy relief (Sistema..., 1999). Samples were collected at depths of 0 to 5,5 to 10 and 10 to $30 \mathrm{~cm}$ during the autumn of 2005.

Hydrophobicity was measured using the Water Drop Penetration Time (WDPT) test, an easy, quick and widespread method which involves placing a drop of water on a soil surface and recording the time elapsed for its complete penetration (Letey, 1969, cited by Doerr, 1998; Hansel et al., 2008). This test was standardized by placing each soil sample on a Petri dish. Then, using a Pasteur pipette, 4 drops ( $\sim 40 \mu \mathrm{L}$ each) of distilled water 
were applied on the soil and the penetration times were measured. The hydrophobicity classification criteria used here were those proposed by Bisdom et al. (1993).

Humic acids (HA) were extracted following the method recommended by the International Humic Substances Society (Swift, 1996), and were characterized spectroscopically by electronic paramagnetic resonance (EPR), fourier transform infra red (FTIR), diffuse reflectance ultraviolet-visible light absorption (DRUVVIS) and fluorescence, and X-ray diffraction techniques. The DRUV-VIS analyses of solid samples were performed with a Shimadzu UV-2401PC spectrometer, equipped with an integration sphere 240-52454-01 and a solid sample cell holder. FTIR spectra were recorded using a Bomen FTIR MB 100 Spectrophotometer. Pellets were obtained by mixing $1 \mathrm{mg}$ of HA and 99 $\mathrm{mg}$ of spectroscopic grade dried $\mathrm{KBr}$. X-ray diffraction analyses were performed using a Shimadzu XRD-6000 diffractometer with $\mathrm{Cu}$ radiation, $\mathrm{CuK} \alpha(\alpha=1,5418 \AA)$, at $40 \mathrm{kV}$ and $40 \mathrm{~mA}$. The range of diffraction angles $\left(10\right.$ to $\left.60^{\circ}, 2 \theta\right)$ was arrayed for 30 minutes. EPR experiments were carried out at room temperature $(\sim 300 \mathrm{~K})$ on a Bruker ESP $300 \mathrm{E}$ spectrometer operating at a $9.5 \mathrm{GHz}$ frequency (X-band), with a $100 \mathrm{kHz}$ modulation frequency, 202.4 T modulation amplitude and $2 \mathrm{~mW}$ microwave power for the HA free radical study. HA free radicals were detected and quantified using the approximation intensity $=\left(\Delta \mathrm{H}_{\mathrm{pp}}\right)^{2}$ at a peak-to-peak line width of $\Delta \mathrm{H}_{\mathrm{pp}}$ (Gonçalves et al., 2000). The areas of the EPR peaks, obtained by integration of the derivative EPR spectra of $5 \mathrm{mT}$ EPR peaks, were calibrated with the peak corresponding to the EPR signal of a reference "weak pitch" of known g-value and free radical content, obtained from Bruker. For the fluorescence analyses, the HAs were reduced to a concentration of $20 \mathrm{mg} \mathrm{L}^{-1}$ and brought to $\mathrm{pH} 8$ by diluting them in a solution of $0.05 \mathrm{~mol} \mathrm{~L}^{-1} \mathrm{NaHCO}_{3}$.

Fluorescence spectra - emission and synchronousscan excitation modes - were acquired with a Perkin Elmer LS-50B luminescence spectrophotometer. The emission and excitation slits were adjusted to a bandwidth of $10 \mathrm{~nm}$ and a scan speed of $500 \mathrm{~nm} \mathrm{~min}{ }^{-1}$ was selected for both monochromators. To obtain the $\mathrm{A}_{4} /$ $\mathrm{A}_{1}$ index (Zsolnay et al., 1999), the area of the last quarter of the spectrum (570-641 nm), acquired in the emission mode with excitation at $240 \mathrm{~nm}$, was divided by the area of the first quarter (356-432 nm). The basic proposal of this method is that humification leads to condensed aromatic rings which would shift the fluorescence emission to red. Therefore, the higher $\mathrm{A}_{4} / \mathrm{A}_{1}$ index the more humified the sample. The $\mathrm{A}_{465}$ index (Milori et al., 2002) corresponded to the area of the spectrum acquired in the emission mode with excitation at $465 \mathrm{~nm}$. Spectra in the synchronous-scan excitation mode, acquired with a $\Delta \lambda$ of $55 \mathrm{~nm}$, were used to calculate the $\mathrm{I}_{454} / \mathrm{I}_{399}$ index (Kalbitz et al., 1999), which was obtained from the ratio of the signal intensity at $454 \mathrm{~nm}$ to the signal intensity at $399 \mathrm{~nm}$.

\section{Results and Discussion}

The repellency test showed a significant difference between the upper soil layer $(0-5$ and $5-10 \mathrm{~cm})$ and the $10-30 \mathrm{~cm}$ layer (Table 1). The surface layer $(0-5$ $\mathrm{cm}$ ), which showed the highest WDPT, was classified as strongly hydrophobic, as was the next layer (5$10 \mathrm{~cm}$ ). These results suggest that surface layers are strongly influenced by the deposition of hydrophobic compounds, which can be originate from litter or from microbiological ativity.

Table 1. Repellency class indicated by water drop penetration time (WDPT) at different depths of an Entisol.

\begin{tabular}{ccc}
\hline $\begin{array}{c}\text { Depth } \\
\text { (cm) }\end{array}$ & $\begin{array}{c}\text { WDPT } \\
(\mathbf{s})\end{array}$ & Repellency class* \\
\hline $0-5$ & 430 & Strongly hydrophobic \\
$5-10$ & 66 & Strongly hydrophobic \\
$10-30$ & 1 & Hydrophilic \\
\hline *According to classes proposed by Bisdom et al. (1993), cited by Doerr (1998)
\end{tabular}

The $\mathrm{A}_{2} / \mathrm{A}_{4}$, ratio increased with soil depth (Table 2), indicating a higher lignin derivative content (absorption at $270 \mathrm{~nm}$ ) in the deeper sample. The $\mathrm{E}_{4} / \mathrm{E}_{6}$ ratio for HAs is usually less than 5.0 and decreases with increasing condensation or organic conjugated structures (Stevenson, 1994; Chen et al., 1977). The HA samples showed a small decrease with soil depth, suggesting a slight increase of their degree of aromaticity. 
Table 2. UV-Vis light absorption ratios at 270 and $407 \mathrm{~nm}\left(\mathrm{~A}_{2} / \mathrm{A}_{4}\right)$, and 465 and $665 \mathrm{~nm}$ wavelengths $\left(\mathrm{E}_{4} / \mathrm{E}_{6}\right)$ of $\mathrm{HA}$, free radical concentration ( in spin $\mathrm{g}^{-1} \times 10^{16}$ ), and corrected g-values of HAs samples extracted from three different depths of an Entisol.

\begin{tabular}{ccccc}
\hline Sampling depth (cm) & $\mathbf{A}_{\mathbf{2}} / \mathbf{A}_{\mathbf{4}}$ & $\mathbf{E}_{\mathbf{4}} / \mathbf{E}_{\mathbf{6}}$ & $\begin{array}{c}\text { Free radical } \\
\left(\text { Spin } \mathbf{~ g}^{\mathbf{1}} \mathbf{)} \mathbf{X} \mathbf{1 0}\right.\end{array}$ & g-factor \\
\hline $0-5$ & 0.71 & 1.11 & 2.96 & 2.0026 \\
$5-10$ & 0.86 & 1.10 & 8.11 & 2.0025 \\
$10-30$ & 0.83 & 1.08 & 8.57 & 2.0027 \\
\hline
\end{tabular}

The FTIR spectra of HAs (Figure 1) are typical for this type of material (Senesi, 2003). A strong absorption broad band in the region of $3400 \mathrm{~cm}^{-1}$ was attributed mainly to the $\mathrm{OH}$ stretching of phenol and alcohol groups. The broadening of these bands is due to the different degrees of hydrogen bonding among the $\mathrm{OH}$ groups and oxygen and/or nitrogen atoms of the present chemical structure. Bands at 2918 and 2850 $\mathrm{cm}^{-1}$ correspond to aliphatic $\mathrm{C}-\mathrm{H}$ stretching $(-\mathrm{CH} 2$ and $\left.-\mathrm{CH}_{3}\right)$, and are less evident in the sample from the greatest depth $(10-30 \mathrm{~cm})$. This result can be explained by the higher concentrations of compounds originated from cutin and suberin, such as alkanoic, alkanedioic and hydroxyalkanoic acids and alkanols, according to findings obtained previously, which indicated the preservation of suberin and cutin biopolyesters (Hansel et al., 2008). Alkyl C from polymethylenic compounds is among the most biologically stable forms of soil organic carbon (Lützow et al., 2006).

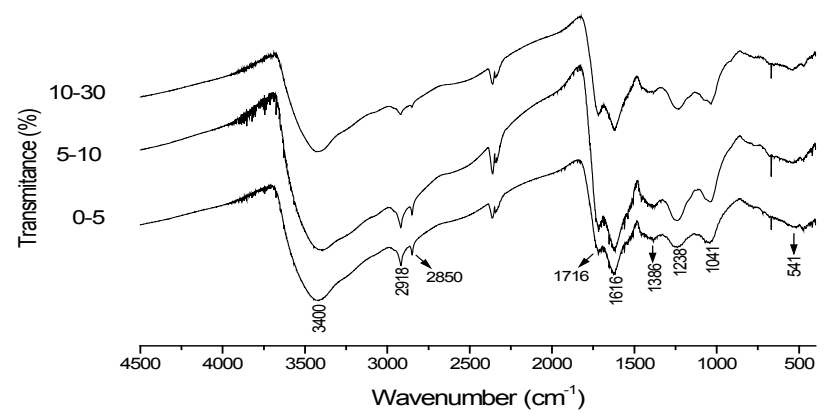

Figure 1. FTIR spectra of humic acid samples from different depths of an Entisol.

The broad bands at around 2,500 and 2,000 $\mathrm{cm}^{-1}$ are due the first overtones of $1,238 \mathrm{~cm}^{-1}$ (C-O of carboxylic group) and 1,041 $\mathrm{cm}^{-1}$ (C-O of carbohydrate), respectively (Janik et al., 2007). The absorption bands at 1,716 $(\mathrm{C}=\mathrm{O}$ stretching of ketonic and carboxylic groups) and at 1,616 $\mathrm{cm}^{-1}$ (aromatic $\mathrm{C}=\mathrm{C}$ and $\mathrm{H}$-bonded $\mathrm{C}=\mathrm{O}$ groups) are also present. From 1,400 to $1,370 \mathrm{~cm}^{-1}$, the absorption bands are due to $\mathrm{O}-\mathrm{H}$ deformation, $\mathrm{C}-\mathrm{H}$ deformation $\left(-\mathrm{CH}_{2} ;-\mathrm{CH}_{3}\right)$ and $\mathrm{COO}^{-}$symmetric stretching. The bands between $1,170-950 \mathrm{~cm}^{-1}$ correspond to absorptions of C-O stretching from alcohols, and/or phenols and/or carbohydrates and Si-O of silicate impurities (Rosa et al., 2000; Stevenson, 1994). Lastly, the absorptions at $541 \mathrm{~cm}^{-1}$ are commonly attributed to $\mathrm{H}-\mathrm{N}$ bending.

The X-ray diffractograms of HA (Figure 2) of humic materials are typical of very amorphous material but can be used to indicate their stability, aromatic origin, and chemical reactivity. The diffractograms can be divided in two main areas: aromatic structure band at around $2 \theta$ of $25,5^{\circ}$ and aliphatic structure band at around $2 \theta$ of $20,5^{\circ}$ (Naidja, 2002). The HA 10-30 cm sample has an evidently more intense aromaticity than that of surface samples.

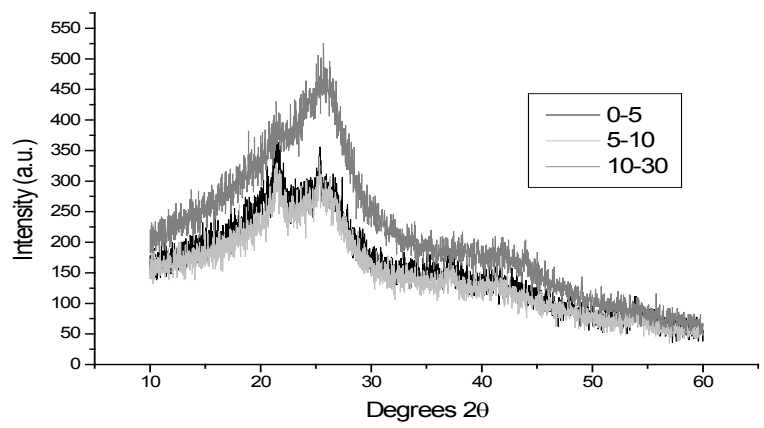

Figure 2. X-Ray diffractograms of humic acids at depths of 0-5, 5-10 and 10-30 (cm) of an Entisol.

The EPR spectra of all the samples in the magnetic field of $505 \mathrm{mT}$ (Figure 3) presented two types of $\mathrm{Fe}^{3+}$ ion domains. The first was a diluted domain attributed to isolated $\mathrm{Fe}^{3+}$ ions occupying distorted sites of the HA structure, which showed a sharp EPR line ( $\mathrm{g}$ 4.3) in a magnetic field lower than $250 \mathrm{mT}$ (Guimarães et al., 2001). The second domain was dominated by 
nonhomogeneously broadened lines due to magnetic dipole-dipole interactions among $\mathrm{Fe}^{3+}$ ion centers $\left(\Delta \mathrm{H}_{\mathrm{pp}}>50 \mathrm{mT}\right.$ and $\left.\mathrm{g} \geq 2\right)$, which is referred to as a concentrated domain. Such domains can be attributed to spin-spin interactions among ions in the oxyhydroxides adsorbed in the HA structure.

The organic free radical signal in the EPR spectra (not shown) of HA samples showed g-values ranging from 2.0025 to 2.0027 , which are typical of free radicals of aromatic organic structures. The concentration of free radicals per gram of HA (Table 2) increased with soil depth. This result is consistent with the X-ray and DRUV-VIS findings.

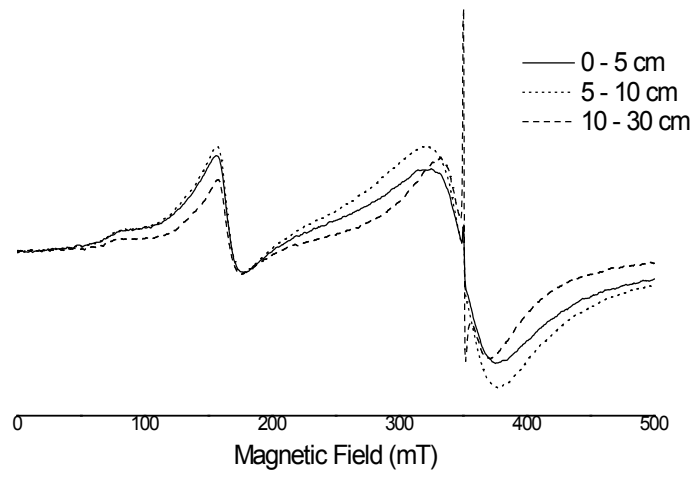

Figure 3. EPR spectra of humic acids extracted from different depths (cm) of an Entisol.

The humification index obtained by fluorescence and calculated by three different methods is accordant (Figure 4). These results showed an increase in the degree of humification down to a depth of $30 \mathrm{~cm}$. Fresh OM from the surface layer contributes to a low degree of humification as a function of the addition of simple structures to the surface soil HA. The degradation and humification processes of organic matter in the first layer, promoted by microorganisms, create more complex structures which possibly migrate to deeper layers. These processes produce an accumulation of these types of structures at greater depths, which increase the molecular complexity of HA.

As soil lipids in surface soil was not removed before humic fractionation, it is reasonable to believe that water repellency in this layer is a complex property, arising from the interaction between different soil organizational components (mainly free lipid, 'fixed' lipid, macroscopic particulate organic matter and the concentration and maturity of humic substances (de Blas et al., 2010; Hansel et al., 2008).

A comparison was made of the fluorescence and EPR results by variation analysis (Figure 5), which showed a high correlation coefficient $(\mathrm{R}=0.92, \mathrm{P}=0.26)$. Both techniques showed an increase of the humification index with increasing soil depth.

A

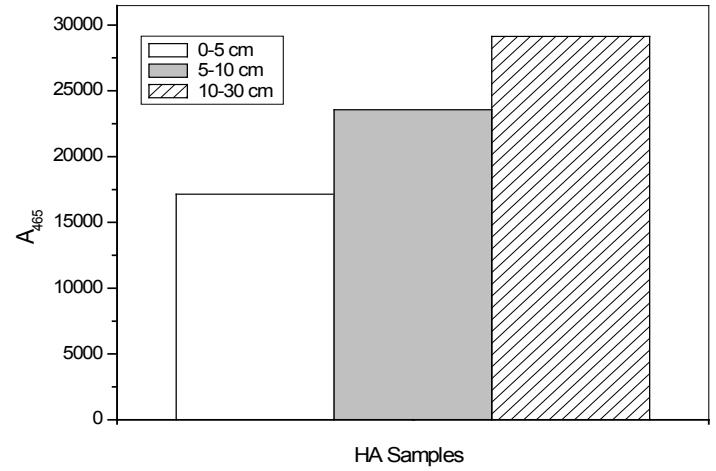

B

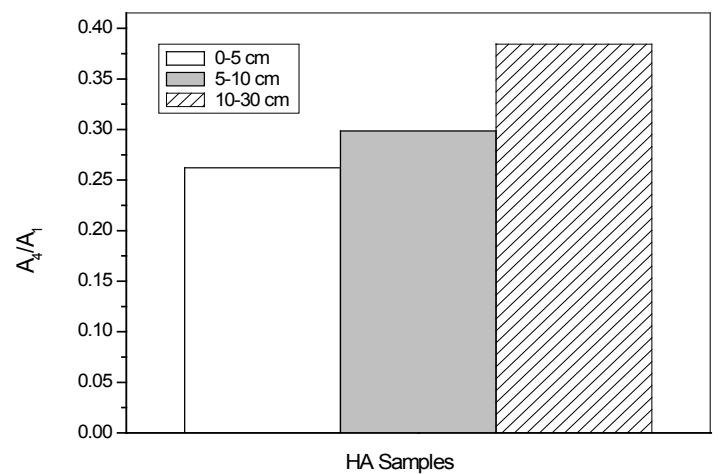

C

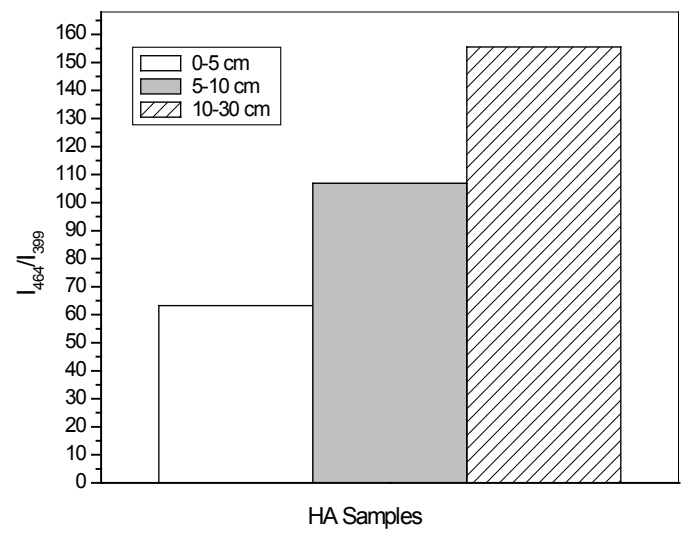

Figure 4. Humification index obtained by different fluorescence methodologies: A) $\mathrm{A}_{465}$ index (Milori et al., 2002), B) $\mathrm{A}_{4} / \mathrm{A}_{1}$ index (Zsolnay et al., 1999), C) $\mathrm{I}_{454} / \mathrm{I}_{399}$ index (Kalbitz et al. 1999). 
Figure 5. Correlation between EPR (Spins $\mathrm{g}^{-1}$ ) and Fluorescence $\left(\mathrm{A}_{465}\right)$ results (according to Milori, et al., 2002 methodology).

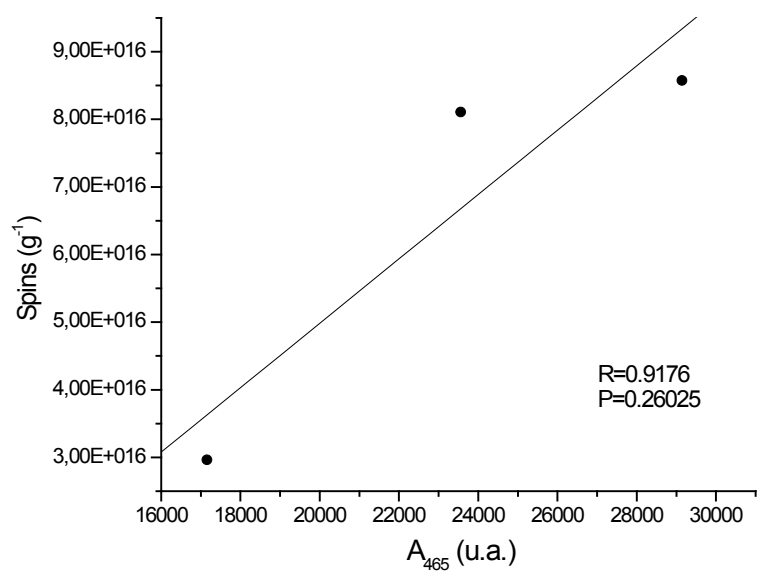

\section{Conclusions}

Spectroscopic characterization of humic acids extracted from an Entisol under pine plantation showed an increasing content of conjugated organic structures and aromatic groups as soil depth increases, indicating higher humification indices, both by fluorescence spectroscopy and EPR.

Aliphatic groups in these fractions are more concentrated in the surface soil layer than in deeper ones, which can be explained by the constant input through litter deposition from loblolly pine plantation. The higher hydrophobicity of the surface soil sample was attributed especially to non-humic components of organic matter, such as those originating from cutin and suberin (alkanoic, alkanedioic and hydroxyalkanoic acids, aromatic compounds, and alkanols), indicating the preservation of suberin and cutin biopolyesters mainly in the topsoil of this pine plantation. Further studies are needed to understand the $\mathrm{C}$ stability in this fraction when compared with humic substances.

\section{Acknowledgements}

The authors thank Iguaçu Celulose e Papel Ltda for allowing them to collect soil samples. Y. C. Cambronero thanks CAPES for a MSc. fellowship.

\section{References}

BACHMANN, J.; GUGGENBERGER G.; BAUMGARTL, T.; ELLERBROCK, R. H.; URBANEK, E.; GOEBEL, M.-O.; KAISER, K.; HORN, R.; FISCHER, W. R. Physical carbonsequestration mechanisms under special consideration of soil wettability. Journal of Plant Nutrition Soil Science, v. 171, p. 14-26, 2008.

BISDOM, E. B. A.; DEKKER, L.W.; SCHOUTE, J. F. T. 1993. Water repellency of sieve fractions from sandy soils and relationships with organic material and soil structure. Geoderma, v. 56, p. 105-118, 1993.

BUCZKO, U.; BENS, O.; HÜTTL, R. F. Variability of soil water repellency in sandy forest soils with different stand structure under Scots pine (Pinus sylvestris) and beech (Fagus sylvatica). Geoderma, v. 126, p. 317-336, 2005.

CAPRIEL, P. Hydrophobicity of organic matter in arable soils: influence of management. European Journal of Soil Science, v. 48, p. 457-462, 1997.

CHEN, Y.; SENESI, N.; SCHNITZER, M. Information provided on humic substances by $E_{4} / E_{6}$ ratios. Soil Science Society of America Journal, v. 41, p. 352-358, 1977.

de BLAS, E., RODRÍGUEZ-ALLERES, M., ALMENDROS, G. Speciation of lipid and humic fractions in soils under pinus and eucalyptus forest in Northwest Spain and its effect on water repplency. Geoderma, v. 155, p. 242-248, 2010.

DOERR, S. H.; SHAKESBY, R. A.; WALSH, R.P.D. Soil water repellency: its causes, characteristics and hydro-geomorphological significance. Earth-Science Reviews, v. 51, p. 33-65, 2000.

DOERR, S. H. On standardizing the 'water drop penetration time' and the 'molarity of an ethanol droplet' techniques to classify soil hydrophobicity: a case study using medium textured soils. Earth Surface Processes and Landforms, v. 23, p. 663-668, 1998.

FOOKEN, U.; LIEBEZEIT, G. Distinction of marine and terrestrial origin of humic acids in North Sea surface sediments by absorption spectroscopy. Marine Geology, v. 164, p. 173-181, 2000.

HANSEL, F. A.; AOKI, C. T.; MAIA, C. M. B. F.; CUNHA JÚNIOR, A; DEDECEK, R. A. Comparison of two alkaline treatments in the extraction of organic compounds associated with water repellency in soil under Pinus taeda. Gneoderma, v. 148, p. 167-172, 2008

GONÇALVES, A. B.; MANGRICH A.S.; ZARBIN, A. J. G.; Polymerization of pyrrole between the layers of alpha-Tin (IV) bis(hydrogenphosphate). Synthetic Metals, v. 114, p. 119-124, 2000.

GUIMARÃES, E.; MANGRICH, A. S.; MACHADO, V. G.; TRAGHETTA, D. G.; LOBO, M. A. Criterious Preparation and Characterization of Earthworm-composts in View of Animal Waste Recycling. Part II. A Synergistic Utilization of EPR and 1H NMR Spectroscopies on the Characterization of Humic Acids from Vermicomposts. Journal of Brazilian Chemistry Society, v. 12, p. 734-741, 2001. 
JANIK, L. J.; SKJEMSTAD J. O.; SHEPHERD K. D.; SPOUNCER, L. R. The prediction of soil carbon fractions using mid-infrared-partial least square analysis. Australian Journal of Soil Research, v. 45, p. 73-81, 2007.

JOBBÁGY, E. G.; JACKSON, R. B. The vertical distribution of soil organic carbon and its relation to climate and vegetation. Ecology Applications, v. 10, p. 423-436, 2000.

KALBITZ, K.; GEYER, W.; GEYER, S. Spectroscopic properties of dissolved humic substances - a reflection of land use history in a fen area. Biogeochemistry, v. 47, p. 219-238, 1999.

LORENZ, K.; LAL, R.; PRESTON, C. M.; NIEROP, K. G. J. Strengthening the soil organic carbon pool by increasing contributions from recalcitrant aliphatic bio(macro)molecules.

Geoderma, v. 142, p. 1-10, 2007.

LÜTZOW, M. V.; KOGEL-KNABNER, I.; EKSCHMITT, K.; MATZNER, E.; GUGGENBERGER, G.; MARSCHNER, B.; FLESSA, H.. Stabilization of organic matter in temperate soils: mechanisms and their relevance under different soil conditions -a review. European Journal Soil Science, v. 57, p. 426-445, 2006.

MILORI, D. M. B. P.; MARTIN-NETO, L.; BAYER, C.; MIELNICZUK, J.; BAGNATO, V. S. Humification degree of soil humic acids determined by fluorescence spectroscopy. Soil Science, v. 167, p. 739-749, 2002.

NAIDJA, A.; HUANG, P. M.; ANDERSON, D. W.; VAN KESSEL, C. Fourier transform infrared, UV-Visible, and X-ray diffraction analysis of organic matter in humin, humic acid, and fulvic acid fractions in soil exposed to elevated $\mathrm{CO} 2$ and $\mathrm{N}$ fertilization. Applied Spectroscopy, v. 56, p. 318-324, 2002.
ROSA, A. H.; ROCHA, J. C.; FURLAN, M. Substâncias Húmicas de turfa: Estudo dos parâmetros que influenciam no processo de extração alcalina. Química Nova, v. 23, p. 472-476, 2000.

SISTEMA brasileiro de classificação de solos. Brasilia, DF: Embrapa Produção de Informação; Rio de Janeiro: Embrapa Solos, 1999. 412p.

SENESI, N.; MIANO T. M.; PROVENZANO, M. R.; BRUNETTI G. Characterization, differentiation, and classification of humic substances by fluorescence spectroscopy. Soil Science, v.152, p. 259-271, 1991.

SENESI, N. Fluorescence spectroscopy applied to the study of humic substances from soil and soil related materials - a review. Abstracts of Papers of the American Chemical Society, v. 199, p. 8,1990 .

STEVENSON, F. J. Humus chemistry: genesis, composition, reaction. 2nd ed., John Wiley \& Sons, New York, 1994, 1022 p.

SWIFT, R. S. Organic matter characterization (Chap 35). In: SPARKS, D. L. et al. (eds). Methods of soil analysis: Chemical methods. Madison, Soil Science Society of America, 1996. Part 3. p. 1018-1020. (Soil Science Society of America, Series, 5).

ZSOLNAY, E.; BAIGAR, M.; JIMENEZ, B.; STEINWEG, N. A.; SACCOMANDI, F. Differentiating with fluorescence spectroscopy the sources of dissolved organic matter in soils subjected to drying. Chemosphere, v. 38, p. 45-50, 1999.

Recebido em 15 de abril de 2010 e aprovado em 20 de outubro de 2010 
